\title{
EXPRESSION OF RECOMBINANT ANTIBODY FRAGMENT, ANTI BNP-SCFV ON THE PERIPLASM OF Escherichia coli FOR THE DETECTION OF HEART FAILURE
}

\section{EKSPRESI FRAGMEN ANTIBODI REKOMBINAN, ANTI BNP-SCFV DALAM PERIPLASMA INANG Escherichia coli UNTUK DETEKSI GAGAL JANTUNG}

\author{
Shabarni Gaffar ${ }^{1 *}$, Sofyan Multazam N. Aji ${ }^{1}$, Yeni W. Hartati ${ }^{1}$, Safri Ishmayana ${ }^{1}$, \\ Toto Subroto ${ }^{1}$ \\ ${ }^{1}$ Departement of Chemistry, Faculty of Mathematics and Natural Sciences, \\ Universitas Padjadjaran, Sumedang, Indonesia \\ *email: shabarni.gaffar@unpad.ac.id
}

Received December 8, 2016; Accepted May 10, 2017; Available online May 30, 2017

\begin{abstract}
ABSTRAK
Basic natriuretic peptide (BNP) merupakan polipeptida yang terdiri dari 32 asam amino yang disekresikan oleh bilik jantung untuk merespon peregangan yang berlebihan pada sel otot jantung. BNP berpotensi untuk digunakan sebagai marker untuk meramalkan pasien yang mengalami gagal jantung. Keberadaan BNP dalam darah dapat dideteksi menggunakan antibodi terhadap BNP yaitu Anti BNP-single chain variable fragment (anti BNP-SCFV). Fragmen antibodi ini merupakan gabungan polipeptida antara daerah yang bervariasi pada rantai heavy $(\mathrm{VH})$ dan rantai light $(\mathrm{VL})$ dari immunoglobulin. Anti BNP-SCFV akan berinteraksi dengan BNP melalui pengenalan antigen-antibodi. Konsentrasi BNP dalam darah pasien dapat dideteksi melalui interaksi BNP dengan Anti BNP-SCFV menggunakan metoda imunosensor. Produksi anti BNP-SCFV rekombinan dalam inang Escherichia coli dilaporkan pada penelitian ini. Anti BNP-SCFV di ekspresikan dalam bentuk fusi dengan peptida sinyal OmpC yang berfungsi untuk mengarahkan ke membran periplasma. Ekspresi dilakukan dibawah promotor RhaBAD dengan menggunakan L-rhamnosa sebagai penginduksi. Karakterisasi dengan SDS-PAGE memperlihatkan pita konsisten pada $28 \mathrm{kDa}$, yang diasumsikan Anti BNPSCFV. Kondisi optimum ekspresi adalah empat jam setelah induksi dengan konsentrasi penginduksi $4 \mathrm{mM}$. Anti BNP-SCFV disekresikan ke luar sel, yang dikarakterisasi dengan ditemukannya fraksi protein pada membran periplasma dan medium kultur.
\end{abstract}

Kata kunci: Anti BNP-SCFV, periplasma, Escherichia coli, BNP

\begin{abstract}
Basic natriuretic peptide (BNP) is a polypeptide hormone consist of 32 amino acids that secreted by the heart ventricle to respond the excessive stretching of heart muscle cells. BNP can be used as prognostic marker for patients with heart failure. The presence of BNP in blood can be detected by BNP antibody, which is anti BNP-single chain variable fragment (Anti BNP-SCFV). The antibody is a combination of polypeptides between varying region on the heavy chain $\left(\mathrm{V}_{\mathrm{H}}\right)$ and the light chain $\left(\mathrm{V}_{\mathrm{L}}\right)$ of immunoglobulin. Anti BNPSCFV will bind to BNP through the antigen-antibody interaction. Concentration of BNP in a patient's blood can be detected through the interaction of BNP with Anti BNP-SCFV using immunosensor method. Production of recombinant Anti BNP-SCFV in Escherichia coli as host is reported in the present study. Anti BNP-SCFV was expressed in fusion form with OmpC signal peptide that direct the protein to a periplasmic space. Expression was performed under RhaBad promoter as control using L-rhamnose as inducer. SDSPAGE characterization showed consistent band at $28 \mathrm{kDa}$, which was assumed as Anti BNP-SCFV. The optimum expression was found at four hours after induction with $4 \mathrm{mM}$ inducer. Anti BNP-SCFV was secreted from the cell as characterized by the presence of the protein on periplasmic membrane and extracellular fraction.
\end{abstract}

Key words: Anti BNP-SCFV, pheriplasmic, Escherichia coli, BNP.

\section{INTRODUCTION}

Heart failure is a condition in which the amount of blood pumped by heart is unable to meet the requirement of normal body's metabolism. This disease is characterized by hemodynamic disturbances where the amount of blood in the heart reduced and increased of ventricular filling pressure is observed (Francis, Gassler \& Sonnenblick, 2005).

BNP (B-type natriuretic peptide) is a neuro-hormone secreted primarily in the heart ventricle to respond the increased volume and pressure of the heart. The presence of BNP is useful for diagnosis of heart failure 
(Longenecker, et al., 2009; Cardarelli \& Lumicao, 2003). BNP concentration increase in patients with left ventricle dysfunction and is associated with the level of severity of the heart disease (Morrison, et al., 2002; Mueller, et al., 2004; Tanfous, Kallel, Jarboui \& Fathallah, 2006). Therefore, BNP antibody is useful for clinical test or to monitor of heart damage.

Recombinant antibody technology is useful to produce antibody molecules that can be used for diagnostic and therapeutic purposes (Hayden, Gilliland \& Ledbetter, 1997). Some formats of recombinant antibodies have been engineered as a diagnostic tool. One of the most recognized recombinant antibodies is the single chain variable fragment (SCFV) which contain varying regions of immunoglobulin, connected with various amino acids (Bach, et al., 2001). SCFV has various structures depends on the recognized molecule. One of advantages of using SCFV is it has small size but still retain antigen binding as an intact antibody molecule.

Anti BNP-single chain variable fragment (Anti BNP-SCFV) will bind to BNP through antigen-antibody specific interaction. The concentration of BNP in patient's blood can be detected by binding of antigenantibody (BNP-Anti BNP-SCFV) using immunometry methods (Maeng, Choi, Sa, Shin,\& Kim, 2012).

Maeng, Nam \& Kim (2011) expressed Anti BNP-SCFV using E. coli expression system. The result of their study indicates that $73.4 \%$ of the recombinant antibodies formed inclusion bodies. E. coli is preferred as expression system because this system has high expression level, cheaper growth media, and easy to scale up for industrial production.

In this study, to prevent the formation of inclusion body, Anti BNP-SCFV was expressed as extracellular protein with OmpC (outer membrane protein C) signal peptide assistance. Native OmpC protein works on the periplasmic membrane (Kudva, et al, 2013), therefore OmpC signal peptide will assists Anti-BNP SCFV export to the periplasm. OmpC signal peptide assists the protein secretion via the Sec-dependent pathway. The secretion of proteins via this pathway is assisted by several secretion factor proteins to carry proteins across the inner membrane to the periplasm and then proceed with the translocation to the extracellular media
(Kudva, et al., 2013; Kotzsch, et al., 2011; Prehna, et al., 2012).

\section{EXPERIMENTAL SECTION}

\section{Materials}

DNA sequence of anti BNP-SCFV was acquired from Gaffar, Mashuri, Hartati \& Rustaman (2016). The gene was designed according to the codon preference of $E$. coli and was constructed in pD861-OmpC expression vector using DNA 2.0 (California, USA). E. coli BL21 (DE3) and Top10F' was purchased from Invitrogen. The growth medium used were: Luria Bertani $(0.5 \%$ yeast extract, $1 \%$ tryptone, $1 \% \mathrm{NaCl}, 2 \%$ bacto agar), SOC $(0.5 \%$ yeast extract, $2 \%$ tryptone, $10 \mathrm{mM} \mathrm{NaCl}, 2.5 \mathrm{mM} \mathrm{KCl}, 10 \mathrm{mM} \mathrm{MgCl} 2,20$ $\mathrm{mM} \mathrm{MgSO} 4,20 \mathrm{mM}$ glucose) and nutrient broth. All materials for growth media were purchased from Oxoid. All chemicals used in the experiments were purchased from Sigma.

\section{Procedures \\ Cloning of anti BNP-SCFV in E. coli}

Recombinant plasmid (pD861-OmpCAntiBNP-SCFV) was propagated in E. coli Top10F' host. Furthermore, pD861-OMPCAnti BNP-SCFV was used to transform $E$. coli BL21 using electroporation methods. Competent cells were prepared according to method described by Gonzales, Brooks, Pukatzki \& Provenzano (2013). Briefly, 5 nanograms of pD861-OMPC-Anti BNPSCFV plasmid were added to $50 \mathrm{~mL}$ competent cells, followed by electroporation at 1500 Volt for 5 seconds using Eppendorf Electroporator 2510. E. coli transformant was resuspended in $1 \mathrm{~mL}$ liquid $\mathrm{SOC}$ medium and incubated for 2 hours at $37{ }^{\circ} \mathrm{C}$, with shaking at $200 \mathrm{rpm}$. The culture was centrifuged, 800 $\mathrm{mL}$ of supernatants was discarded, the pellet was resuspended, $100 \mu \mathrm{L}$ of culture was grown on solid LB medium containing kanamycin $(250 \mathrm{mg} / \mathrm{mL})$ and incubated at 37 ${ }^{\circ} \mathrm{C}$ for 18 hours.

\section{Anti BNP-SCFV expression}

Before the protein expression was conducted, the growth curve of $E$. coli transformants was measured. One colony of E. coli BL21 [Anti BNP-SCFV] were grown in $25 \mathrm{~mL}$ of liquid $\mathrm{LB}$ medium. $\mathrm{OD}_{600}$ was measured every hour up to 20 hours to determine the growth curve.

One colonies of E. coli BL21 [Anti BNP-SCFV] was grown in $5 \mathrm{~mL}$ of liquid LB 
medium containing kanamycin $(250 \mathrm{mg} / \mathrm{mL})$ with shaking at $200 \mathrm{rpm}$ for 18 hours at $37^{\circ} \mathrm{C}$. One $\mathrm{mL}$ of culture was transferred into the Erlenmeyer flask containing $100 \mathrm{~mL}$ of liquid LB containing kanamycin. The cultures was incubated at $37{ }^{\circ} \mathrm{C}$, with shaking at $200 \mathrm{rpm}$ until $\mathrm{OD}_{600}$ reach 0.7. One millilitre of culture was taken as $\mathrm{t}-0$ samples ( 0 hours before induction with L-Rhamnosa). Samples were collected in micro tubes, and then the cell pellet and supernatant were separated by centrifugation. Furthermore, $4 \mathrm{mM}$ LRhamnose was added into the culture, incubation was continued at $37{ }^{\circ} \mathrm{C}$ with shaking at $200 \mathrm{rpm}$ up to18 hours. Two millilitres samples were taken every hour until 18 hour after induction. The cell pellet was separated from the supernatant by centrifugation at $3000 \mathrm{~g}, 4^{\circ} \mathrm{C}$ for 10 minutes. Furthermore $500 \mathrm{~mL}$ of Tris-EDTA pH 6.8 was added into the pellets and resuspended. The cells was lysed by using Sonicator (Sonics vibra cell). The lysis process consists of 2 seconds on and two seconds off for five minutes. The lysate was centrifuged at 10,000 $g, 4{ }^{\circ} \mathrm{C}$ for 10 minutes. Supernatant was transferred to a new tube as a soluble fraction and characterized by SDS-PAGE.

\section{Extraction of periplasmic protein}

Periplasmic protein was extracted by adding $100 \mu \mathrm{L}$ of Tris-Sucrose-EDTA (TSE) buffer $\mathrm{pH} 8$ to the tube that contain cell pellet. Cell was resuspended, then incubated on ice for 30 minutes, and centrifuged at $10.000 \mathrm{~g}, 4$ ${ }^{\circ} \mathrm{C}$ for 30 minutes. The supernatant which contain periplasmic protein extract was transferred into new tube (Quan, et al., 2013).

\section{Extracellular protein extraction.}

The extracellular fractions of proteins were collected from culture supernatant after centrifugation at $3000 \mathrm{~g}, 4{ }^{\circ} \mathrm{C}$ for $10 \mathrm{~min}$. The supernatant was concentrated $10 \mathrm{x}$ using freeze-dryer (Eppendorf).

\section{Extraction of insoluble fraction protein}

Insoluble protein fraction was isolated by addition of $70 \mu 18 \mathrm{M}$ urea to the sonicated pellet, then boiled at $95{ }^{\circ} \mathrm{C}$ for $15 \mathrm{~min}$ and centrifuged at $10.000 \mathrm{rpm}, 4{ }^{\circ} \mathrm{C}$ for $10 \mathrm{~min}$. The supernatant which contain insoluble protein was transferred into new tube.

\section{Optimization of inducer concentration}

Concentration of L-rhamnosa trialled were 4, 5, 6, $7 \mathrm{mM}$. Each optimization process was performed in a $25 \mathrm{~mL}$ liquid $\mathrm{LB}$ media with the addition of kanamycin $(250 \mathrm{mg} / \mathrm{mL})$. Protein expression was performed at $37{ }^{\circ} \mathrm{C}$ with $200 \mathrm{rpm}$ shaking speed. Each culture of E. coli BL21 [Anti BNP-SCFV] was induced with different concentration of L-Rhamnose when $\mathrm{OD}_{600}$ value reached \pm 0.7 . The cultures were harvested at $4^{\text {th }}$ hour after induction and analyzed for soluble (S), insoluble (I), periplasmic $(\mathrm{P})$ and extracellular $(\mathrm{M})$ proteins with previously mentioned method.

\section{Growth medium selection}

In addition to inducer concentration, optimization of culture medium for protein expression was also conducted. Growth medium used were Nutrient broth (NB), Luria-Bertani broth (LB) and Luria-Bertani broth 2-fold (LB2x). Protein expression were characterized by SDS-PAGE.

\section{SDS-PAGE analysis}

Sodium dodecyl sulfate-polyacrylamide gel electrophoresis was performed at reduced condition using $12 \%$ polyacrylamide as running gel and $4 \%$ polyacrylamide as stacking gel. Twenty microliter of each protein fraction was analyzed by SDS-PAGE. Protein band were detected using Coomassie brilliant blue dye.

\section{RESULTS AND DISCUSSION}

Based on the growth curve (data not shown), it was found that the $\log$ phase of $E$. coli BL21 [Anti BNP-SCFV] occurred between the $3^{\text {rd }}$ to $5^{\text {th }}$ hour after induction. The $\mathrm{OD}_{600}$ for induction was ranging from 0.4 to 0.7 .

Protein expression was performed by addition of $4 \mathrm{mM}$ L-rhamnosa as inducer to $10 \mathrm{~mL}$ expression culture at the end of the $\log$ phase (4 hours after induction). The result of cytoplasmic protein fraction is presented on Figure 1. It was found that there were a lot of soluble protein present in the cytoplasm, and a band at $\sim 28 \mathrm{kDa}$ which correspond to the Anti BNP-SCFV molecular weight was present. This band become more dense starting 3 hours after induction.

The band has relatively constant thickness after the $3^{\text {rd }}$ hour. This data suggests that the protein is always produced by positive regulation under rhaBAD promoter control in the presence of L-rhamnosa in the cytoplasm. Anti BNP-SCFVis expressed as a fusion with OmpC signal peptide, therefore anti BNPSCFV which has been expressed in the cytoplasm, will be translocated to the 
periplasm. An SDS PAGE result of the periplasmic protein fraction is presented on Figure 2.

SDS-PAGE analysis of periplasmic protein fraction showed that the $28 \mathrm{kDa}$ protein band did not appear at $t_{0}$, but was detected at $\mathrm{t}_{1}-\mathrm{t}_{14}$ and than dissappeared. We assumed that Anti BNP-SCFV was translocated into the periplasmic space, characterized by $\sim 28 \mathrm{kDa}$ band at $\mathrm{t}_{1}-\mathrm{t}_{14}$. However the band dissapear after $\mathrm{t}_{14}$, probably because the protein was translocated to extracellular medium. This is possible because anti BNP-SCFV was express as fusion with OmpC peptide signal that act to translocate protein across the membrane. The result of extracellular protein characteri-zationis shown in Figure 3. It can be seen that longer induction time, lead to higher expression of extracellular protein fraction, even though $E$. coli also secrete other proteins out of the cell.
Based on the protein analysis of the cytoplasm, periplasm and extracellular fractions, it was found that before induction (t-0), only small amount of Anti BNP-SCFV were detected in the cytoplasm and none detected in the periplasmic or extracellular fractions. After 3 hours of induction, Anti BNP-SCFVwas expressed more, compared to non induced culture. At t-3 Anti BNPSCFVwas detected in the periplasmic fraction but not in the extracellular medium. Anti BNP-SCFV expressed as a fusion with OmpC signal peptide, that direct secretion through the sec-dependent pathway that consists of two stages, i.e. translocation into the periplasmic space and then translocation to the outside of the cell (Prehna et al., 2012). After 18 hours induction, Anti BNP-SCFV protein was undetectable in periplasm, but appear as thick bands in the extracellular media.

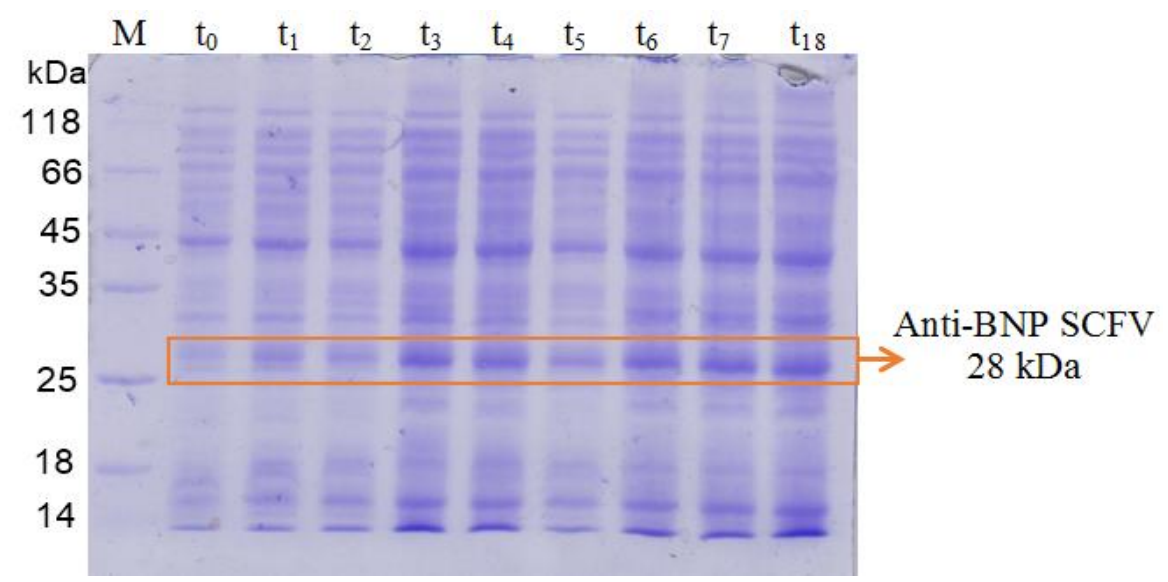

Figure 1.SDS-PAGE analysis on $12 \%$ polyacrylamide of soluble protein fractions expressed by E. coli BL21[Anti BNP-SCFV] with $4 \mathrm{mM}$ L-rhamnosa as inducer. (M) Protein marker; $\left(\mathrm{t}_{0}\right)$ protein fraction before induction; $\left(\mathrm{t}_{\mathrm{i}}\right)$ protein fraction after induction at $\mathrm{i}^{\text {th }}$ - hours.

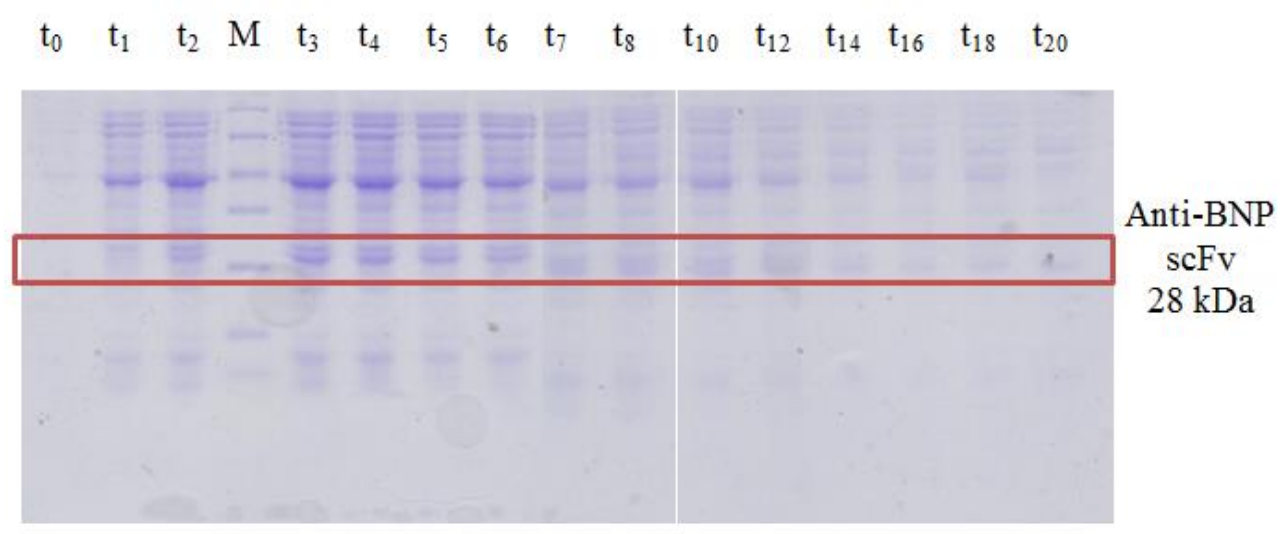

Figure 2.SDS-PAGE analysis on $12 \%$ polyacrilamide of periplasmic proteins. (M) Protein marker; $\left(\mathrm{t}_{0}\right)$ protein fraction before induction; $\left(\mathrm{t}_{\mathrm{i}}\right)$ protein fraction after induction at $\mathrm{i}^{\text {th }}$-hour. 


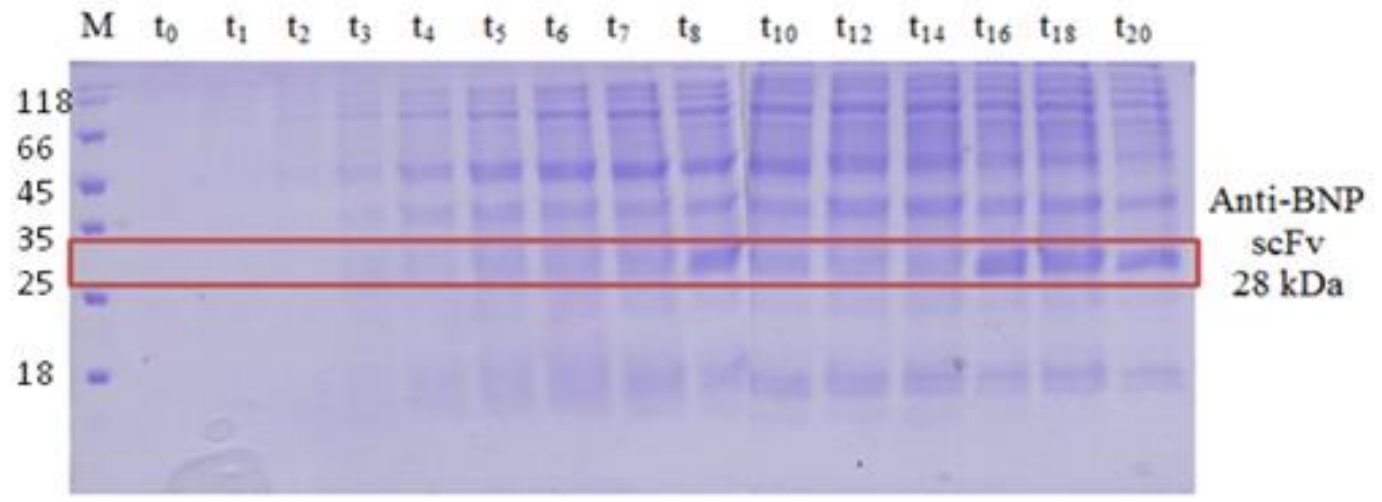

Figure 3. SDS-PAGE analysis on $12 \%$ polyacrylamide of extracellular protein produced by E. coli [Anti BNP-SCFV]. (M) Protein marker; $\left(\mathrm{t}_{0}\right)$ protein fraction before induction; $\left(\mathrm{t}_{\mathrm{i}}\right)$ protein fraction after induction at i-hours.

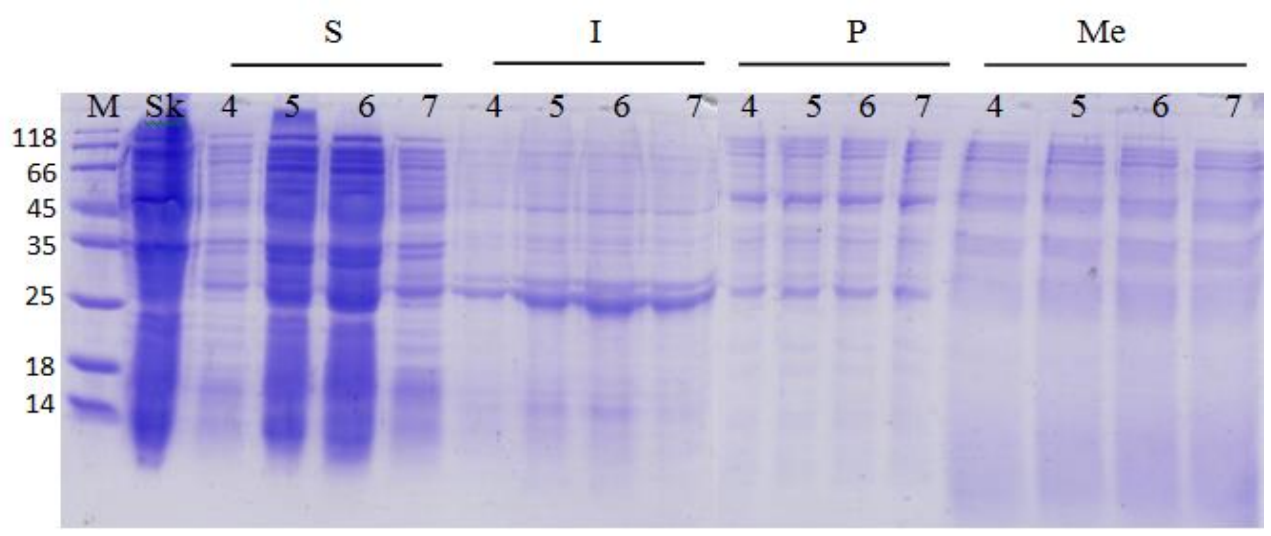

Figure 4. SDS-PAGE analysis on $12 \%$ polyacrylamide result of optimization of inducer concentration. (M) Protein marker; (Sk) E. coli BL21 (DE3) wild type; (S) soluble protein fraction; (I) insoluble protein fraction; (P) periplasm protein fraction; $(\mathrm{Me})$ extracellular protein fraction; (4) $4 \mathrm{mM}$ L-rhamnosa; (5) $5 \mathrm{mM}$ L-rhamnosa; (6) $6 \mathrm{mM}$ L-rhamnosa; (7) 7 mM L-rhamnosa.

\section{Optimization of Inducer Concentration}

Optimization of expression was performed to determine the optimum conditions required to produce optimal expressed protein. There are many factors that affect protein expression, one of which is the concentration of inducer. Inducers serves to initiate the regulatory process, both positive and negative regulators. This study used rhaBAD promoter that induced by Lrhamnosa. Increasing L-rhamnosa concentrations proportional to the increase of the rate expression and it will affect the amount of protein produced, as well as the effect on the secretion of proteins out of the cell associated with efficient systems in $E$. coli BL21. Therefore inducer concentration needs to be optimized.

The concentration range of L-rhamnosa trialled were 4, 5, 6 and $7 \mathrm{mM}$. Cultures were harvested 4 hour after the induction as mentioned before, then each fraction were analyzed for its soluble (S), insoluble (I), periplasmic $(\mathrm{P})$ and extracellular medium (M) proteins. SDS-PAGE characterization results is presented on Figure 4.

The SDS-PAGE result demonstrated that increasing inducer concentration increases the formation of inclusion bodies or insoluble proteins in the cell. The thickness of the protein band secreted into the periplasm was similar for all inducer concentration. This indicated that the increased expression is not equal to the rate of protein secretion out of the cell, therefore many heterologous protein stuck in the cytoplasm and not secreted, forming inclusion bodies.

These results indicate that increasing inducer concentration not always promote expression of the target protein in a particular expression systems. For extracellular expression system which depend on limited secretion factors, the high rate of expression will only make the protein retained in the cells 
and less effective for translocation. Therefore, $4 \mathrm{mM}$ inducer concentration was chosen as the optimum condition, because the amount of protein produced was relatively high and the insoluble protein fraction was not too high.

\section{Growth Medium Selection}

In addition to inducer concentration, optimization of growth medium was also performed. Growth medium is an important factor associated with source of nutrients for the cells to grow and multiply. Three types of growth media were trialled: Nutrient broth (NB), Luria-Bertani broth (LB) and LuriaBertani broth 2-fold (LB2x).E. coli BL21 [Anti BNP-SCFV] colonies was grown on each medium and induced with $4 \mathrm{mM} \mathrm{L-}$ rhamnosa as previously descibed. SDS-PAGE analysis of periplasmic protein is presented on Figure 5.

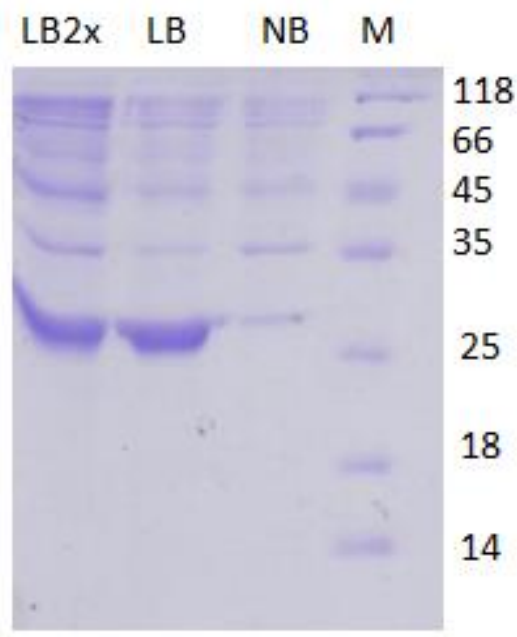

Figure 5. SDS-PAGE analysis on $12 \%$ polyacrylamide of periplasm protein extracted from E. coli[Anti BNP-SCFV] culture using various growth media. $\left(\mathrm{LB}_{2 \mathrm{x}}\right)$ Luria-Bertani broth concentration 2-fold; (LB) Luria-Bertani broth; (NB) Nutrient broth; (M) protein marker.

Based on the results of Anti BNPSCFV expression level in different growth medium it was found that the protein bands produced in LB and LB2x media have the similar thickness, while for NB only a thin band was detected. This is presumably due to the nutritional content of NB medium that less supportive for the growth of $E$. coli when compared to the LB medium. Therefore growth rate of the cells and the amount of secreted protein was lower compared to LB media. 2-fold concentrated LB media did not show any differences compared to the result of 1-fold LB medium. This is due to the type of nutrients present in the media are same. Higher concentration of nutrients did not give any effect on the results of protein expression, because $E$. coli itself has a limited ability to absorb nutrients.

\section{CONCLUSION}

Recombinant antibody fragments Anti BNP-SCFV (28 kDa) was successfully expressed in E. coli BL21 host and secreted using OmpC signal peptide to periplasm and extracellular space. However the characterization by western blot and purification process still needs to be performed. Optimization of inducer concentration showed that increasing inducer concentrations increases the formation of inclusion bodies. LB-1x medium was a suitable medium for the expression of Anti BNP-SCFV.

\section{REFERENCES}

Bach, H., Mazor, Y., Shaky, S., Shoham-Lev, A., Berdichevsky, Y., Gutnick, D.L., Benhar, I. (2001) Escherichia coli maltose-binding protein as a molecular chaperone for recombinant intracellular cytoplasmic single chain antibodies.

Journal of Molecular Biology. 312: 7993. DOI: 10.1006/jmbi.2001.4914

Cardarelli, R., Lumicao, T.G.Jr. (2003). Btype natriuretic peptide: A review of its diagnostic, prognostic, and therapeutic monitoringvalue in heart failure for primary care physicians. Journal of American Board of Family Medicine. 16(4): 327-333. Doi:10.3122/jabfm.16. 4.327

Francis, G.S., Gassler, J.P. \& Sonnenblick, E.H. (2005). Pathophysiology and Diagnosis of Heart Failure. In: Fuster V, Alexander R.W, O'Rourke R.A. The Heart 10 ${ }^{\text {th }}$ ed.1: 655-685.

Gaffar, S., Masyhuri, A.A., Hartati, Y.W., Rustaman. (2016). In silico study of single chain variable fragment (SCFV) selective to B-type Natriuretic Peptide (BNP) hormone. Jurnal Chemica et Natura Acta, 4(2): 52-59.

Gonzales, M.F., Brooks, T., Pukatzki, S.U. \& Provenzano, D. (2013). Rapid protocol for preparation of electrocompetent Escherichia coli and Vibrio cholera. Journal of Visualized Experiments. 8(80):1-6. doi: 10.3791/50684. 
Hayden, M.S., Gilliland, L.K., Ledbetter, J.A. (1997). Antibody engineering. Current Opinion of Immunology. 9:201-212.

Kotzsch, A, Vernet, E., Hammarstrom, M., Berthelsen, J., Weigelt, J., Graslund, S., and Sundstrom, M. (2011). A secretory system for bacterial production of highprofile protein targets. Protein Science. 20: 597-609. Doi: 10.1002/pro.593.

Kudva, R., Denks, K., Kuhn, P., Vogt, A., Muller, M. \& Koch, H.G. (2013). Protein translocation Across The Inner Membrane of Gram-Negative Bacteria: The Sec and Tat Dependent Protein Transport Pathways. Research in Microbiology.164: 505-534. doi: 10.1016/j.resmic.2013.03.016.

Longenecker, K.L., Ruan, Q., Fry, E.H., Saldana, S.C., Brophy, S.E., Richardson, P.L. \& Tetin, S.Y. (2009). Crystal structure and thermodynamic analysis of diagnostic Mab 106.3 complexed with BNP 5-13 (C10A). Proteins.76: 536-547.

Maeng, B.H., Choi, J., Sa, Y.S., Shin, J.H. \& Kim, Y.H. (2012). Functional expression of recombinant anti-BNP SCFV in methylotrophic yeast Pichia pastoris and application as a recognition molecule in electrochemical sensors. World Journal of Microbiology and Biotechnology. 28(3): 1027-1034. DOI 10.1007/s11274-011-0901-5.

Maeng B.H., Nam D.H., Kim Y.H. (2011). Co expression of molecular chaperones to enhance functional expression of antiBNP SCFV in the cytoplasm of Escherichia coli for the detection of Btype natriuretic peptide. World Journal of Microbiology and Biotechnology.
27:1391-1398. Doi: 10.1007/s11274010-0590-5.

Morrison, L.K., Harrison, A., Krishnaswamy, P., Kazanegra, R., Clopton, P., Maisel, A. (2002).Utility of a rapid Bnatriuretic peptide assay in differentiating congestive heart failure from lung disease in patients presenting with dyspnea. Journal of the American College Cardiology 39(2):202-209. https://doi.org/10.1016/S0735$\underline{\text { 1097(01)01744-2 }}$

Mueller, C., Scholer, A., Laule-Kilian, K., Martina, B., Schindler, C., Buser, P., Pfisterer, M., Perruchoud, A.P. (2004). Use of B-type natriuretic peptide in the evaluation and management of acute dyspnea. The New England Journal of Medicine. $\quad 350: 647-654 . \quad$ Doi: 10.1056/NEJMoa031681.

Prehna, G., Zhang, G., Gong, X., Duszyk, M., Okon, M., McIntosh, L.P., Weiner, J.H. \& Strynadka, N.C. (2012). A protein export pathway involving Escherichia coli porins. Structure. 20:11541166. Doi: 10.1016/j.str.2012.04.014.

Quan, S., Hiniker, A., Collet, J.F., Bardwell, J.C. (2013). Isolation of bacteria envelope proteins. Method in Molecular Biology. 966: 359-366. Doi: 10.1007/978-1-62703-245-2_22.

Tanfous, N.G.B., Kallel, H., Jarboui, M.A. \& Fathallah, D.M. (2006). Expression in Pichia pastoris of a recombinant SCFV form of MAb 107, an anti human CD11b integrin antibody. Enzyme and Microbial Technology. 38, 636-642. https://doi.org/10.1016/j.enzmictec.200 5.07.014. 